\title{
The Consequences \\ Financing Prompt Treatment Until Terminal of HIV AIDS in Universal Health Coverage
}

\author{
Ernawaty ${ }^{1}$, Nuzulul Kusuma Putri ${ }^{1}$ and Lilis Masyfufah ${ }^{2}$ \\ ${ }^{1}$ Faculty of Public Health, Universitas Airlangga, Mulyorejo Street, Surabaya, Indonesia \\ ${ }^{2}$ STIKES Yayasan Dr. Soetomo, Karangmenjangan Street No. 12, Surabaya, Indonesia \\ \{ernawaty,nuzululkusuma\}@fkm.unair.ac.id, lilismasyfufahas@gmail.com
}

Keywords: HIV AIDS, health insurance, treatment cost

\begin{abstract}
Even though almost entire chronic diseases are covered in Universal Health Coverage, the mechanisms for financing aggregate HIV AIDS treatment costs are different between countries. This study aims to forecast the financing consequences of providing financial protection for HIV AIDS patients through National Health Insurance in Indonesia. It analyzed hospital financial report of patients along early NHI implementation. Data are retrieved from biggest referral hospital in eastern Indonesia. The cost is compared based on cost drivers of treatment. This financial map then forecast according to developing rate of HIV AIDS in Indonesia. This study shows that HIV AIDS treatment mostly paid by health insurance. At least people spent IDR 4,298,250 for each inpatient treatment. The biggest cost is derived by laboratory examination which spent more than $10 \%$ of total treatment cost. Most of HIV AIDS patients seek for treatment in emergency situation which mean that already in chronic phase. It will bear huge amount of HIV AIDS treatment cost considering that it is chronic diseases with many number of cases. Dominant cost drivers of country, donor spending on HIV treatment and medical prevention become important to consider when calculating financial ability providing in financing the HIV AIDS patients.
\end{abstract}

\section{INTRODUCTION}

Human Immunodeficiency Virus (HIV) is a virus that attacks the human immune system. People living with HIV have a weak body's ability to fight against infectious diseases. Weak immune system causes health problems, such as fever, cough, and diarrhoea constantly. A collection of symptoms caused by a weak immune system is called Acquired Immune Deficiency Syndrome (AIDS).

The number of HIV AIDS patients in Indonesia has increased. New cases of HIV in Indonesia have reached 7.146 people only until in first semester of 2016. The high number of people living with HIV in Indonesia will bring any societal problems. Moreover, they also risk by economic burden of disease. A study by Kuhlmann et al.(2017) showed that this group burdened by $40 \%$ higher from the gross domestic product per capita in country. This study also mentioned that people living with HIV are not merely burdened by their treatment cost but also opportunity loss. People living with HIV are demanding more not only in social assistance but also financial assistance (Lindayani et al. 2017).

Since 2014 the implementation of National Health Insurance in Indonesia has been started, HIV AIDS became one of the diseases covered by the insurance agency. It relieved people living with HIV from the high amount of treatment cost. Unfortunately, Bhattacharya et al. (2003) in his study revealed that despite insurance participation will decline the number of premature death, public insurance is less effective than private insurance.

In the other hand, the rapid growth of HIVAIDS number in Indonesia significantly affects the financial of BPJS Kesehatan as the organizer of National Health Insurance. The increasing number of HIV AIDS cases will also increase the expense of public insurance, moreover it is also chronic disease which cannot be healed and should be treat as long as the patients live. The purpose of this research was to forecasting the financing consequences of providing financial protection for HIV AIDS patients through National Health Insurance in Indonesia. 